\title{
THE INFLUENCE OF CONTEXTUAL TEACHING AND LEARNING APPROACH AND STUDENTS' GENDER ON MATHEMATICS UNDERSTANDING AT GRADE IV SDN ALANG LAWAS, PADANG
}

\author{
Remiswal $^{1}$, Dorisno ${ }^{2}$ \\ 1,2 Universitas Islam Negeri Imam Bonjol Padang, Indonesia \\ ${ }^{1}$ remiswal@uinib.ac.id, ${ }^{2}$ dorisno@uinib.ac.id
}

\begin{abstract}
The purpose of this study was to describe differences in the understanding of students who learned through CTL approach and students who learned through the conventional approach, to observe the differences in the Mathematics understanding of male students and female students, and to see the interaction between the learning approach and gender on the mathematics understanding. The type of this research was a Quasi Experimental Design with a factorial design (2x2 factorial design). The population in this study was all fourth grade students at SDN Alang Lawas Padang. The samples were students at SDN 37 Alang Lawas as the control class and students at SDN 20 Alang lawas as the experimental class. The results of the research concluded that (1) there were differences in the mathematical understanding of students who were taught by CTL approach and the students who were taught by a conventional approach; (2) there were differences in the mathematical understanding of male students and female students at grade IV SDN Alang Lawas; and (3) there was no significant interaction between learning approaches and gender in influencing students' mathematical understanding.
\end{abstract}

Keywords: CTL, Mathematics, gender

\section{PENGARUH PENDEKATAN CONTEXTUAL TEACHING AND LEARNING DAN JENIS KELAMIN TERHADAP PEMAHAMAN MATEMATIKA SISWA KELAS IV SDN ALANG LAWAS KOTA PADANG}

\begin{abstract}
ABSTRAK
Tujuan penelitian ini untuk menjelaskan perbedaan pemahaman peserta didik yang belajar dengan Pendekatan CTL dan peserta didik yang belajar menggunakan Pendekatan Konvensional, melihat Perbedaan pemahaman peserta didik laki-laki dan peserta didik perempuan pada mata pelajaran Matematika. dan melihat adakah interaksi antara pendekatan pembelajaran dengan jenis kelamin dalam mempengaruhi pemahaman Matematika. Jenis penelitian ini adalah Quasi Eksprimental Design dengan rancangan factorial design (desain faktorial 2x2). Adapun Populasi dalam penelitian ini seluruh siswa kelas IV SDN Alang Lawas Padang dengan sampel SDN 37 Alang Lawas sebagai kelas kontrol dan SDN 20 Alang lawas sebagai kelas eksperimen. Hasil penelitian dan pembahasan dapat disimpulkan (1) terdapat perbedaan pemahaman matematika peserta didik yang diajar menggunakan Pendekatan CTL dengan pemahaman matematika peserta didik yang diajar menggunakan pendekatan konvensional di kelas IV SDN Alang lawas. (2) terdapat perbedaan pemahaman matematika peserta didik laki-laki dengan pemahaman matematika peserta didik perempuan di kelas IV SDN Alang lawas, dan (3) tidak adanya interaksi yang signifikan antara pendekatan pembelajaran dengan jenis kelamin dalam mempengaruhi pemahaman Matematika peserta didik.
\end{abstract}

Kata Kunci: CTL, matematika, jenis kelamin

\begin{tabular}{|c|c|c|}
\hline Submitted & Accepted & Published \\
\hline 28 Mei 2021 & 19 Juli 2021 & 29 Juli 2021 \\
\hline
\end{tabular}

\begin{tabular}{|l|c|c|c|}
\hline Citation & $:$ & $\begin{array}{r}\text { Remiswal, R., \& Dorisno, D. (2021). The Influence of Contextual Teaching and Learning Approach and Students' Gender } \\
\text { on Mathematics Understanding at Grade IV SDN Alang Lawas, Padang. Jurnal PAJAR (Pendidikan dan } \\
\text { Pengajaran), 5(4), 1134-1140. DOI : http://dx.doi.org/10.33578/pjr.v5i4.8426. }\end{array}$ \\
\hline
\end{tabular}

\section{PENDAHULUAN}

Matematika merupakan ilmu yang berguna bagi kehidupan manusia, dengan ilmu matematika seorang mampu berfikir logis, kritis dan bisa melakukan perhitungan dalam kehidupan sehari-hari. Mata pelajaran Matematika sudah diajarkan sejak mulai dari SD sampai perguruang tinggi. Depdiknas, (2006:416), menyatakan bahwa
"Tujuan Matematika diajarkan di SD adalah untuk membekali peserta didik dengan kemampuan berfikir logis, analitis, sistematis, kritis, dan kreatif, serta kemampuan bekerjasama". Kemampuan tersebut diperlukan supaya peserta didik dapat, mengelola, dan memanfaatkan informasi untuk bertahan hidup pada keadaan saat 
sekarang ini yang selalu berubah, tidak pasti, dan kompetitif.

Matematika merupakan mata pelajaran yang berperan sebagai pelajaran untuk matematika itu sendiri maupun ilmu lainnya. Penguasaan matematika harusnya diperoleh sejak dini. Dengan demikian, dapat menunjang keberhasilan siswa untuk menempuh pendidikan selanjutnya seperti ke perguruan tinggi.

Tujuan pembelajaran Matematika sesuai dengan Permendiknas No.22 Tahun 2006 adalah melatih pesertadidik untuk memahami konsep Matematika, mengembangkan kemampuan dalam menarik kesimpulan, menyelesaikan masalah dan mengkomunikasikan gagasan, serta menata cara berfikir dan pembentukan keterampilan sehingga mengubah tingkah laku peserta didik. Selain itu, tujuan pembelajaran matematika di Sekolah Dasar adalah peserta didik cekatan dalam memanfaatkan ilmu konsep matematika untuk menyelesaikan masalah dalam kehiduoan sehari-hari. Contohnya dalam membagi satu buah kue untuk dua orang maka konsep yang digunakan adalah konsep matematika.

Berbagai upaya telah dilakukan dalam meningkatkan kualitas pembelajaran, terutama pelajaran matematika mulai dari perubahan kurikulum. Perubahan kurikulum dimaksudkan untuk menyesuaikan standar isi pelajaran dengan perkembangan ilmu pengetahuan dan teknologi. Kualitas pendidik juga diperbaiki mulai dari adanya KKG (Kelompok Kerja Guru). KKG merupakan wahana para guru untuk berdiskusi tentang masalah yang dihadapi di kelas serta memberikan inovasi baru dalam proses pembelajaran. Selain itu, pemerintah juga meningkatkan sarana dan prasarana pendidikan seperti menambah buku-buku pelajaran.

Kenyataan akan rendahnya hasil belajar Matematika pesertadidik, tidak terlepas dari bagaimana proses pembelajaran yang berlangsung selama ini. Salah satu faktor yang mempengaruhi keberhasilan proses pembelajaran adalah pendekatan yang digunakan dalam proses pembelajaran itu. Pendekatan belajar yang tepat akan memudahkan peserta didik dalam mencerna materi yang dipelajari. Dalam pembelajaran Matematika banyak kemungkinan pendekatan yang dapat digunakan seperti pendekatan konvensional dan pendekatan CTL.

Pendekatan pembelajaran konvensional dipandang kurang efektif, karena proses pembelajarannya membuat siswa kurang aktif dan pembelajaran berpusat pada guru. Pembelajaran Matematika berbeda dengan pelajaran lain bahkan kebanyakan peserta didik menganggap pelajaran matematika adalah pelajaran yang sulit. Sehingga dapat dilihathasil belajar peserta didik pada pelajaran Matematika rendah. Dalam mempelajari matematika tidak cukup hanya dengan menghafal, tetapi jugadiperlukan pemahaman, ketelitian dan latihan secara terus-menerus. Dengankata lain mempelajari matematika perlu keaktifan peserta didik.Wallace (1992) menjelaskan pendekatan konvensional memandang guru menjadi peran utama dalam pembelajaran dan propses pembelajaran guru mengajarkan materi kepada siswa

Pembelajaran yang konvensional akan menciptakan suasana yang monoton sehingga siswamenjadi bosan dalam pembelajaran. Menurut Heruman (2012) untuk meningkatkan kompetensi pesertadidik guru harus mengubah gaya belajar pasif menjadi aktif. dengan kata lain pendekatan pembelajaran yakni pembelajaran yang mengkontruk pengetahuan sehingga pembelajaran bermakna dan menyenangkan bagi pesertadidik.

Pendekatan Contextual Teaching and Learning (CTL) jika dibandingkan pendekatankonvensional lebih banyak keunggulan. Pendekatan Kontekstual merupakan salah satu pendekatan belajar yang mampu menghidupkan kelas supaya peserta didik belajar dengan sesungguhnya. Taufik dan Muhammadi, (2012:189) menjelaskan bahwa "Pendekatan Kontekstual merupakan suatu model pembelajaran dimana guru menghadirkan situsasi dunia nyata ke dalam kelas dan mendorong peserta didik membuat hubungan antara pengetahuan yang dimilikinya dengan penerapannya dalam kehidupan mereka". Jadi pendekatan kontekstual dapat menghubungkan pengetahuan yang dimiliki oleh pesertadidik dengan situasi dunia nyata.

Keberhasilan suatu proses pembelajaran tidak hanya ditentukan oleh pemilihan dan 
penggunaan metode atau pendekatan pembelajaran saja. Akan tetapi ada banyak faktor yang mempengaruhinya, diantaranya adalah perbedaan jenis kelaminantar peserta didik. Dilihat dari perbedaan jenis kelamin antara lakilaki dan perempuan juga mempengaruhi gaya belajar peserta didik dalam menyelesaikan matematika. laki-laki lebih aktif dalam belajar dibandingkan perempuan. Penelitianyang dilakukan Rushton (2006), menjelaskan bahwa perbedaan prestasi belajar laki-laki dan perempuan lebih disebabkan oleh perbedaan tingkat intelegensi.

Geary (2000) pada penelitiaanya juga menjelaskan bahwa laki-laki lebih aktif dari perempuan. Gearymenyatakan bahwa pengaruh faktor jenis kelamin dalam matematika disebabkan adanya perbedaan biologis dalam otak anak laki-laki dan perempuan. dari hasil observasi, dimana anak perempuan lebih baik dibidang bahasa dan menulis sementara anak laki-laki lebih unggul dibidang matematika karena kemampuan keruangan anak laki-laki lebih baik.

Menurut Nafi'an keunggulan anak lakilaki dalam bidang matematika yakni pada bidang penalaran, sementara anak perempuan dalam bidang ketepatan, ketelitian, kecermatan berfikir, dan juga laki-laki memiliki pemahaman yang baik dibanding anak perempuan. Perbedaan ini pada tingkat sekolah dasar belum begitu terlihat namun akan lebih nampak pada tingkat yang lebih tinggi.

Berdasarkan fenomena tersebut apakah ada hubungan antara pendekatan/model yang digunakan dengan jenis kelamin pesertadidik dalam proses belajar matematika. Oleh karena itu, penulis melakukan penelitian dengan judul "Pengaruh Pendekatan CTL Terhadap Pemahaman Matematika Siswa Kelas IV Berdasarkan Jenis Kelamin di SDN Alang lawas Padang”.

\section{METODE PENELITIAN}

Dalam pemilihan metode penelitian, penulis menggunakan pendekatan kuantitatif dalam bentuk Quasi Eksprimental Design. Perlakuan pendekatan CTL diberikan kepada kelas eksperimen dan kelas kontrol sebagai pembanding yang mana menggunakan pendekatan konvensional. Ada tiga variable dalam penelitian ini yakni variabal bebas yakitu pendekatan pembelajaran, yang menjadi variable terikat yaitu hasil belajar berupa pemahaman belajar dan variable moderator yaitu jenis kelamin.

Penelitian ini dilaksanakan di SDN Alang lawas. Dari 6 sekolah yang ada pada Gugus 1 kecamatan Padang Selatan, dipilih dua kelas secara random untuk dijadikan sebagai kelas eksperimen dan kelas kontrol. Penelitian untuk Kelas eksperimen dilaksanakan di SDN 20 Alang Lawas sedangkan penelitian kelas kontrol dilaksanakan di SDN 37 Alang lawas. Untuk uji coba tes hasil belajar dilakukan di SDN 01 Alang Lawas. Waktu penelitian dilaksanakan pada semester genap TA 2019/2020. Penelitian ini dimulai pada tanggal 17 Februari sampai 4 Maret 2020.

Populasi pada penelitian ini adalah seluruh peserta didik kelas IV SDN Alang Lawas yang terdaftar pada semester genap TA 2019/2020 yang terdiri dari 6 sekolah.

Teknik yang digunakan dalam penarikan sampel adalah Random Sampling. Teknik ini digunakan karena populasi mempunyai anggota/unsur yang homogen secara proporsional. Berdasarkan populasi yang ada, untuk memilih sampelnya dilakukan uji normalitas, uji homogenitas, dan uji kesamaan rata-rata. Sampel adalah perwakilah dari populasi yang benar-banar mewakili populasi itu sendiri. Trianto (2009: 256) menyatakan bahwa "Sampel adalah sebagian atau wakil populasi yang diteliti".

Pengambilan sampel peneliti lakukan dengan teknik random sampling, yaitu dipilih secara acak. Pengambilan sampel dilakukan dengan cara Lot. Dari pengundian terpilih SD N 20 AlangLawas sebagai kelas eksperimen dan SDN 37 Alanglawas sebagai kelas kontrol.

Variabel penelitian adalah sesuatu yang menjadi objek penelitian, menurut Yusuf (2013: 101) "Variabel pada hakikatnya merupakan konsep yang mempunyai variasi nilai". Penelitian ini memuat terdapat tiga variabel dengan uraian sebagai berikut: Variabel bebas pada penelitian ini adalah Pendekatan CTL dan pendekatan konvensional, Variabel terikat pada penelitian ini adalah hasil belajar pada tingkatan $\mathrm{C} 2$ 
(Pemahaman/ Undestanding), dan Variabel moderator jenis kelamin

Data dalam penelitian ini berbentuk angka-angka atau data kuantitatif yang mana terdiari dari dua sumber data, data primer dan data skunder. Data primer diperileh dari hasil tes soalsoal intrumen kepada pesserta didik yang telah diberi perlakuan dengan pendekatan CTL dan pendekatan konvensional, data sekunder yakni data tidak dari sumber data lansung atau pihak-pihak tertentu seperti dari pegawai tata usaha sekolah, data nilai UH 2 pada mata pelajaran matematika di SDN Alang Lawas Padang Selatan kota Padang

Desain atau rancangan peneltian yang penulis gunakan adalah factorial design yakni suatu rancangan yang memperhatikan adanya variabel moderator yang mempengaruhi perlakuan variable independen terhadap variable dependen faktorial 2 x 2), (Yusuf, 2013: 191). Desain penelitain ini terlihat dari tabel di bawah ini.

Tabel 1.Rancangan Penelitian Factorial Design

\begin{tabular}{|c|c|c|c|}
\hline & \multicolumn{2}{|c|}{ Pendekatan } \\
\hline & & $\operatorname{CTL}\left(\mathrm{A}_{1}\right)$ & Konvensional $\left(\mathrm{A}_{2}\right)$ \\
\hline \multirow{3}{*}{$\begin{array}{c}\text { Jenis } \\
\text { Kelamin }\end{array}$} & $\begin{array}{c}\text { Laki-laki } \\
\left(\mathrm{B}_{1}\right)\end{array}$ & $\left(\mathrm{B}_{1}, \mathrm{~A}_{1}\right)$ & $\left(\mathrm{B}_{1}, \mathrm{~A}_{2}\right)$ \\
\hline & $\begin{array}{c}\text { Perempuan } \\
\left(\mathrm{B}_{2}\right)\end{array}$ & $\left(B_{2}, A_{1}\right)$ & $\left(\mathrm{B}_{2}, \mathrm{~A}_{2}\right)$ \\
\hline & & $\left(\mathrm{B}_{1}, \mathrm{~A}_{1}\right)+\left(\mathrm{B}_{2}, \mathrm{~A}_{1}\right)$ & $\left(\mathrm{B}_{1}, \mathrm{~A}_{2}\right)+\left(\mathrm{B}_{2}, \mathrm{~A}_{2}\right)$ \\
\hline
\end{tabular}

Instrumen yang digunakan pada penelitian ini yaitu lembar tes hasil belajar. Data dalam penelitian ini diperoleh dengan menggunakan insrtumen tes hasil belajar.

\section{HASIL DAN PEMBAHASAN Hasil}

Setelah proses penelitian selesei dilaksanakan, selanjutnya didapat hasil tes pemahaman matematika antara kelas eksperimen dan kelas kontrol, sebelum dilakukan uji hipotesis terlebnih dahulu dilakukan uji prasyarat analisis yaitu data hasil tes kemapuan pemahaman matematika siswa kelas eksperimen yang diajar dengan CTL dan data hasil tes kemampuan pemahamanmatematika siswa yang diajar dengan konvensional. uji prasyarat analisis dilakukan dengan uji normalitas yakni dengan uji liliefors dan uji homogenitas dengan menggunakan uji F. Untuk melihat apakah data kedua kelas sampel berdistribusi normal atau tidak dilakukan uji normalitas. Hasil dari uji normalitas diperoleh data berdistribusi normal, setelah dilakukan uji normalitas selanjutnya dilakukan uji homogenitas dengan tujuan untuk melihat apakah data kedua kelas sample mempunyai varian yang homogen, dari hasil uji homogenitas terlihat kedua kelas mempunyai varian yang homogen.

Hipotesis penelitian diuji dengan analisi varians dua arah. Untuk menguji data dengan analisis varian dua arah harus terpenuhi asumsi bahwa data berdistribusi normal dan homogen sebagaimana yang dinyatakan Riduwan (2013) sebelum melakukan pengujian hipotesis prasyarat analisis data harus normal dan homogen.

Setelah prasyarat analisis data terpenuhi selanjutnya diolah data dengan analisis varians dua arah, hasil perhitungan analisis dua arah dapat dilihat secara ringkas dalam tabel 2 berikut. 
Jurnal PAJAR (Pendidikan dan Pengajaran)

Volume 5 Nomor 3 April 2021 | ISSN Cetak : 2580 - 8435 | ISSN Online : 2614 - 1337

DOI : http://dx.doi.org/10.33578/pjr.v5i4.8437

Tabel 2. Hasil Perhitungan Anava Dua Arah

\begin{tabular}{|c|c|c|c|c|c|}
\hline Sumber Variansi & JK & db & KR & F Hitung & F Tabel \\
\hline Antar (A) & 677,53 & 1 & 677,53 & 5,002 & \multirow{5}{*}{4,04} \\
\hline Antar (B) & 1025,04 & 1 & 1025,04 & 7,568 & \\
\hline Antar (AB) & 33,20 & 1 & 33,20 & 0,245 & \\
\hline Dalam (D) Residu & 6636,10 & 49 & 135,43 & & \\
\hline Total & 8371,87 & 52 & - & & \\
\hline
\end{tabular}

Berdasarkan tabel di atas terlihat hasil perhitungan ANAVA untuk Hipotesis pertama yang diajukan diperoleh nilai $\mathrm{F}$ Hitung $=5.002$ dan $\mathrm{F}$ Tabel $=$ 4.04. Dengan taraf signifikansi 5\% maka $F_{\text {hitung }}>F_{(\text {tabel })}$, berarti hipotesis $\mathrm{H}_{0}$ ditolakdan hipotesis penelitian diterima. Dapat disimpulkan bahwa terdapat perbedaan pemahaman belajar peserta didik yang diajar menggunakan Pendekatan CTL dengan pemahaman belajar peserta didik yang diajar menggunakan pendekatan konvensional di kelas IV SDN Alang Lawas.

Hasil analisis hipotesis kedua diperoleh nilai $\mathrm{F}_{\text {Hitung }}=7.568$ dan $\mathrm{F}$ Tabel $=4.04$. Dengan taraf signifikansi $5 \%$ maka $F_{\text {hitung }}>F_{(\text {tabel })}$, berarti hipotesis $\mathrm{H}_{0}$ ditolak dan $\mathrm{H}_{1}$ diterima. Artinya terdapat berbedaaan pemahaman matematika siswa laki-laki dan siswa perempuan

Hipotesis ketiga diperoleh nilai $\mathrm{F}$ Hitung $=$ 0.245 dan $F$ Tabel= 4.04. Dari hasil perhitungan diperoleh kesimpulan Antar grup $(\mathrm{AB}) \mathrm{f}_{\text {hitung }}<\mathrm{f}$ tabel maka $\mathrm{H}_{\mathrm{o}}$ diterima artinya tidak terdapat interaksi yang signifikan antara pendekatan pembelajaran dengan jeniskelamin dalam mempengaruhi pemahaman konsep Matematika peserta didik.

\section{Pembahasan}

Berdasarkan hasil pengujian hipotesis dapat dijabarkan sebagai berikut:

1. Perbedaan Pemahaman Belajar Peserta Didik yang Diajar Menggunakan Pendekatan CTL dengan Pemahaman Belajar Peserta Didik yang Diajar Menggunakan Pendekatan Konvensional di Kelas IV SDN Alang Lawas.
Hipotesis yang pertama diuji pada penelitian ini adalah adalah melihat terdapat atau tidaknya perbedaan pemahaman belajar peserta didik yang diajar menggunakan pendekatan CTL dengan pemahaman belajar peserta didik yang diajar menggunakan pendekatan konvensional. Data pengujian hipotesis menunjukkan terdapat perbedaan pemahaman belajar kelas yang diberi perlakuan pendekatan CTL dengan kelas yang belajar dengan pendekatan konvensional Hasil tes pemahaman matematika peserta didik pada kelas eksperimen lebih tinggi jika dibanding dengan hasil tes pemahaman matematika peserta didik kelas control.

Peserta didik pada kelas eksperimen terlihat antusian dalam mengikuti pembelajaran, mulai dari kesiapan belajar mereka terlibat menyiapkan media belajar dengan menyiapkan benda-benda disekitar yang berbentuk bangun ruang, setelah itu siswa mengamati benda-benda tersebut sesuai dengan arahan guru dan digiring menemukan konsep yang ingin dicapai waktu pembelajaran, siswa terlihat aktif dalam belajar karena siswa terlibat menemukann konsep dan bekerja sesuai dengan Lembar kerja peserta didik (LKPD) yang sudah disiapkan. Berbeda dengan pembelajaran menggunakan pendekatan konvensional siswa menerima penjelasan dari guru dan tidak terlibat dalam menemukan konsep, hal ini membuat siswa cenderung bosan dalam belajar.

Peningkatan pemahaman konsep juga terbukti melalui penelitian yang dilakukan oleh Dafinah dkk (2019) dari hasil penelitian terbukti pendekatan CTL meningkatkan pemahaman konsep peserta didik pada siklus I $75 \%$ dan naik pada siklus II menjadi 86\%, hal senada juga diungkapkan Eka Yuliani dkk (2019) pada 
penelitiannya diperoleh terdapat peningkatan kemampuan matematis siswa kelas III SD yang diajar dengan pendekatan CTL.

\section{Perbedaan Pemahaman Belajar Peserta Didik yang Diajar Menggunakan Pendekatan CTL Berdasarkan Jenis Kelamin di Kelas IV SDN Alang Lawas.}

Hasil analisis data yang diperoleh, terdapat perbedaan pemahaman belajar peserta didik yang diajar menggunakan pendekatan CTL dan Konvensional berdasarkan jenis kelamin. Hal ini dapat dilihat pada tes akhir peserta didik yang diberikan kepada kelas eksperimen. Pada proses pembelajaran pada kelas eksperimen terlihat peserta didik laki-laki lebih aktif untuk bertanya dan tampil ke depan dibandingkan peserta didik perempuan.

Menurut kajian American Psychological Association dalam lestari (2010) percaya diri lakilaki lebih tinggi dari perempuan dalam matematika namun kemampuan matematika perempuan tidak terlalu buruk dari kemampuan laki-laki, dan perempuan dari Negara yang telah mengakui kesetaraan gender menunjukkan hasil yang baik dalam tes matematika. Maccoba dan jacklyn juga mengatakan perbedaan laki-laki dan perempuan dalam belajar matematika adalah laki-laki lebih unggul dalam penglihatan keruangan sedangkan perempuan lebih unggul dalam kemampuan verbal.

Beberapa para ahli mengatakan bahwa kemampuan penguasaan matematika dan pemecahan masalah antara peserta didik laki-laki dan perempuan memiliki perbedaan dalam segi keruangan. Oleh karena itu, pada penelitian ini antara kelompok laki-laki dan perempuan memiliki pemahaman Matematika yang berbeda.

\section{Interaksi Antara Pendekatan Pembelajaran dengan Jenis Kelamin Dalam Mempengaruhi Pemahaman Belajar Siswa Kelas IV SDN Alang Lawas.}

Pengujian hipotesis ketiga pada penelitian ini yaitu melihat apakah ada interaksi antara pendekatan pembelajaran dengan jenis kelamin dalam mempengaruhi pemahaman belajar siswa kelas IV SDN Alang Lawas. Berdasarkan analisis data yang diperoleh, Tidak terdapat interaksi antara pendekatan pembelajaran dengan jenis kelamin dalam mempengaruhi pemahaman belajar siswa kelas IV SDN Alang Lawas. Hal ini bisa dilihat pada tes akhir peserta didik yang diberikan kepada peserta didik. Dengan tidak adanya interaksi ini menunjukkan bahwa, tanpa memperhatikan jenis kelamin peserta didik proses pembelajaran dengan menggunakan pendekatan CTL dan pendekatan konvensional dapat dilaksanakan.

Artinya pendekatan CTL bisa saja diterapkan untuk meningkatkan pemahaman belajar peserta didik tanpa harus memperhatikan jenis kelamin peserta didik. Peserta didik laki-laki maupun peserta didik perempuan cocok diajar dengan pendekatan CTL ini. artinya pendekatan pembelajaran tidak tergantung pada jenis kelamin dalam mempengaruhi kemampuan pemahaman belajar.

\section{SIMPULAN DAN REKOMENDASI}

Berdasarkan hasil penelitian yang telah penulis paparkan di atas, maka dapat disimpulkan:

1. Terdapat perbedaan pemahaman belajar peserta didik yang diajar menggunakan Pendekatan CTL dengan Pemahaman belajar peserta didik yang diajar menggunakan Pendekatan Konvensional di kelas IV SDN Alang Lawas.

2. Terdapat perbedaan pemahaman matematika peserta didik laki-laki dan peserta didik perempuan yang diajar menggunakan Pendekatan CTL di kelas IV SDN Alang Lawas.

3. Tidak ada interaksi antara pendekatan pembelajaran dengan jenis kelamin dalam mempengaruhi pemahaman belajar peserta didik kelas IV SDN Alang Lawas.

Berdasarkan simpulan di atas penulis kemukakan rekomendasi sebagai berikut:

1. Bagi guru agar menggunakan pendekatan yang tepat dalam pembelajaran, pahami karakteristik pendekatan/model pembelajaran agar efektif penggunakan pendekatan dalam pembelajaran sehingga tujuan pembelajaran tercapai. Pendekatan CTL direkomendasikan untuk digunakan dalam pembelajaran karena terbukti meningkatkan pemahaman konsep peseta didik. Dengan penggunaan pendekatan 
CTL pembelajaran akan bermakna bagi peserta didik dan peserta didik akan membangun pengetahuannya sendiri. Dalam pembelajaran dikelas guru perlu melihat perbedaan kemampuan peserta didik berdasarkan jenis kelamin karena terbukti tidak sama kemampuan pemahaman matematika laki-laki dan perempuan.

2. Bagi kepala sekolah agar mendorong dan membimbing guru dalam menggunakan pendekatan/model pembelajaran di kelas

3. Bagi peneliti lainnya bisa mengembangkan penelitian ini menjadi lebih luas dengan memperhatikan kekurangan dan keterbatasan penelitian ini

\section{DAFTAR PUSTAKA}

Arikunto, S. (2003). Dasar-Dasar Evaluasi Pendidikan (Edisi Revisi). Jakarta: PT Bumi Aksara.

Depdiknas. (2001). Kurikulum Tingkat Satuan Pendidikan. Jakarta: Depdiknas.

Ghasani, D. (2019). Penerapan Pendekatan CTL Untuk Meningkatkan Pemahaman Konsep Matematis Siswa Kelas V SD. Jurnal Pendidikan Guru Sekolah Dasar. 4 (III), 91-99.

Heruman. (2012). Model Pembelajaran Matematika di sekolah Dasar, Bandung: Remaja Rosda Karya

Lestari, N.D.F. (2010). Profil Pemecahan Masalah Matematika Open-Ended SiswaKelas V Sekolah Dasar Ditinjau dari Perbedaan Gender dan KemampuanMatematika. Tesis. Surabaya: Unesa

Mukhlis. (2012). Model Pembelajaran CTL, (Online),

(http://mukhliscaniago.wordpress.com/20 12/02/24/model-pembelajaran-ctl/, diakses pada tanggal 20 Desember 2020)

Muliyardi. (2002). "Pengembangan Model Pembelajaran Matematika Menggunakan Komik di Kelas I Sekolah Dasar". Disertasi tidak diterbitkan. Surabaya: Universitas Negeri Surabaya

Pemerintah RI. (2003). Undang-Undang Sistem Pendidikan Nasional No.22 tahun 2003. Jakarta: Depdiknas.
Riduwan. (2013). Dasar-dasar Statistika. Bandung : Alfabeta

Santrock, Jhon W. (2007). Perkembangan Anak, Edisi Ketujuh, Jilid Dua. Jakarta:Erlangga

Taufik, T. (2012). Mozaik Pembelajaran Inovatif. Padang: Sukabina Press.

Trianto. (2010). Mengembangkan Pembelajaran tematik.Jakarta: Kencana.

Uno, H., dan Koni, S. (2012). Assessment Pembelajaran. Jakarta: Bumi Aksara.

Upton, P. (2012). Psikologi Perkembangan. Jakarta:Erlangga

Wallace. (1992). Pendekatan Konservatif. Tersedia di www.duniapelajar.com > Pend. Matematika

Yuliani, E., dkk. (2019). Penerapan Model Contextual Teaching And Learning (CTL) Untuk Meningkatkan Pemahaman Matematis Peserta Didik Sekolah Dasar. Jurnal educare, 17(2), 85-165. Diakses 25 April 2021 